\title{
BIGH3: A Negative Regulator of Human Osteosarcoma Large Multicellular Spheroids
}

\author{
Brian S. Thoma, Robert J. Moritz, Fatemeh Rezapoor, Chandler T. Sargent, \\ Clyde F. Phelix, Richard G. LeBaron*
}

Department of Biology, The University of Texas at San Antonio, One UTSA Circle, San Antonio, TX, USA

Email: *Richard.lebaron@utsa.edu

How to cite this paper: Thoma, B.S., Moritz, R.J., Rezapoor, F., Sargent, C.T., Phelix, C.F. and LeBaron, R.G. (2016) BIGH3: A Negative Regulator of Human Osteosarcoma Large Multicellular Spheroids. International Journal of Clinical Medicine, 7, 771791.

http://dx.doi.org/10.4236/ijcm.2016.711084

Received: September 30, 2016

Accepted: November 26, 2016

Published: November 29, 2016

Copyright $\odot 2016$ by authors and Scientific Research Publishing Inc. This work is licensed under the Creative Commons Attribution International License (CC BY 4.0).

http://creativecommons.org/licenses/by/4.0/

\begin{abstract}
Numerous studies have demonstrated a relationship between the extracellular matrix protein BIGH3 and variations in the malignant properties of different cancer cell types, including osteosarcoma cells. BIGH3 protein can suppress and promote tumor growth, even on the same cancer cell type, indicating that contextual cues regulate BIGH3-mediated divergent outcomes. We employed a multicellular tumor spheroid model to study the effects of BIGH3 with respect to physical and molecular features of three-dimensional tumor growth. The results demonstrated that exogenous recombinant BIGH3 blocked the development of multicellular large tumor spheroids so that only small spheroids formed. The effect was dependent on the BIGH3 concentration in the growth medium and the time of incubation of BIGH3 with the osteosarcoma cells in the spheroid model. TGF- $\beta 1$ signaling induced multicellular tumor spheroids to synthesize a greater quantity of BIGH3 relative to non-treated spheroids. The TGF- $\beta 1$-mediated increase in BIGH3 protein antagonized the development of multicellular large spheroids. Anti-BIGH3 antibody, and an inhibitor of TGF- $\beta 1$ signaling, blocked the antagonistic effect induced through TGF- $\beta 1$ stimulation and BIGH3 protein expression, resulting in the formation of multicellular large spheroids. Immunohistochemistry detected BIGH3 at cell bodies within the spheroid stroma, suggesting osteosarcoma cell-surface proteins bind BIGH3. Flow cytometry demonstrates that osteosarcoma cells interact with soluble BIGH3, and solid-phase cell adhesion assays show that osteosarcoma adhesion to BIGH3 substratum is mediated by integrin $\alpha 4 \beta 1$. However, anti- $\alpha 4$ antibody did not attenuate the BIGH3mediated antagonism toward formation of multicellular large spheroids. We conclude that TGF $\beta 1$ and BIGH3 suppress the development of large osteosarcoma tumors.
\end{abstract}

\section{Keywords}

Cancer, 3-Dimensional, TGF $\beta 1$, Extracellular Matrix, TGFBI, Beta-ig 


\section{Introduction}

As an in vitro model of tumor progression, propagation of Multicellular Tumor Spheroids (MTS) provides a convenient means to study the effects of the extracellular matrix (ECM) on tumor formation. Various tumor cell types have been propagated as MTS comprising cells and their ECM, and exhibiting behavior similar to that of tumors in vivo [1]. It is well established that cells on two-dimensional substrates of various polyresin plastics provide valuable information regarding ECM synthesis, cell signaling, propagation and viability, tissue regeneration, and cellular and molecular mechanisms underlying disease. Relative to cells propagated as a 2-dimensional monolayer, MTS are superior representations of the physiology of solid tumorigenesis. Extending in vitro cell culture methodology, three-dimensional intermediate model systems provide the convenience of culturing cells in the context of a complex environment of one or more cell types and their provisional ECM [2] [3] [4]. Relative to cells propagated as a 2-dimensional monolayer, MTS are superior representations of the physiology of solid tumorigenesis. Tumor spheroids comprise cells that are at the spheroid surface, within intermediate stroma, and in a centralcore, which can become a necrotic environment [5]. Molecules of the ECM can play significant roles in tumor progression, mechanically stabilizing and affecting tumor morphology and tumor cell viability and metastasis [1] [6] [7]. The human gene called TGFBI encodes for the ECM protein BIGH3, which was discovered investigating the effects of the cytokine TGF $\beta 1$ on adenocarcinoma tumor progression [8]. The BIGH3 gene was cloned and sequenced in 1992 [8], and subsequently BIGH3 was proposed to function as a tumor suppressor protein [9]. TGFBI mice exhibited predisposition to develop various tumors, underscoring BIGH3's tumor suppressing property. Isolated $\mathrm{T} F B I^{-1}$ mouse embryonic fibroblasts showed chromosomal abnormalities, increased cyclin D1 synthesis, and cell proliferation [10]. BIGH3 suppressed proliferation of osteosarcoma [11], lung [12] [13] [14] [15], ovarian [16] [17] [18], breast [19], prostate cancer cells [12], and exhibited anti-angi- ogenic and anti-tumorigenic activities [20]. In contrast, other studies show that BIGH3 protein stimulates cancer cell aggressiveness, including osteosarcoma metastasis [21], colon cancer [22], oral squamous carcinoma [23] [24], and astrocytoma progression [25]. Integrins, apoptosis [11], chromosomal abnormalities [26], and cell motility and chemoresistance to lung and ovarian cancer cells [27] have been implicated in molecular mechanisms that underlie BIGH3's divergent effects on tumors progression. Central to $\mathrm{BIGH} 3$ biology is a strong response of the BIGH3 gene to TGF- $\beta 1$ stimulation [9], and the regulatory action in play between TGF- $\beta 1$ and integrins [28] [29]. Thus, TGF- $\beta 1$ staining is a contextual cue for transcription, translation and secretion of BIGH3. Despite the accumulating evidence of differential roles that BIGH3 mediates in different cancer and cancer cell types, there has been a paucity of information on the effect of BIGH3 protein on cancer cell behavior in the context of a three-dimensional tumor environment. We previously reported BIGH3 mediates apoptosis in MG-63 osteosarcoma cell monolayers [11]. To this end we sought to examine the effect of BIGH3 on developing osteosarcoma tumor spheroids by using a simple yet well-recognized MTS model 
system as a convenient method to examine tumor response to ECM protein. Here, we utilized osteosarcoma MG-63 cells, MG-63 BIGH3, human recombinant BIGH3 protein, and TGF- $\beta 1$ to test for BIGH3' influence on osteosarcoma MTS.

\section{Methods}

MG-63 cells were purchased from the American Type Culture Collection (ATCC \# CCL-1427; Rockville, MD). Chinese Hamster Ovary (CHO) cells expressing human recombinant BIGH3 have been described [30]. Dulbecco's Modified Eagle Medium (DMEM), Glasgow Minimum Essential Medium (GMEM), non-essential amino acids, antibiotics, salmon sperm DNA and sodium pyruvate were purchased from Invitrogen (San Diego, CA). FBS was from Irvine Scientific (Santa Ana, CA). Paraformaldehyde, Cell Dissociation Solution, EDTA, l-asparagine monohydrate, nucleosides, methionine sulfoximine, agarose, heparin-agarose, Proteinase K, 3,3'-diaminobenzidine tetrahydrochloride (DAB), cycloheximide, Hoechst 33258 (bisBenzamide) and rabbit IgG were purchased from Sigma- Aldrich (St. Louis, MO). Flow cell YM membrane and Centricon microfiltration capsules were purchased from Amicon, Inc. (Beverly, MA). Mono-Q and hydroxyapatite bio-scale columns were purchased from Bio-Rad Laboratories (Hercules, CA). Superfrost Plus microscope slides were purchased from VWR Scientific Products (Sugarland, TX). Purchased from Chemicon International (Temecula, CA) were anti-bovine fibronectin antibodies and monoclonal antibodies against human integrin subunit $\beta 1$ (clone 6S6) $\alpha 4$ (clone P1H4). Goat anti-rabbit immunoglobulin-G (IgG) conjugated to fluorescein-5-isothiocyanate (FITC), goat anti-mouse IgG conjugated to FITC and Cell Proliferation Reagent WST-1 (4-[3-(4-Iodophenyl)2-(4-nitrophenyl)-2H-5-tetrazolio]- 1,3-benzene disulfonate) were purchased from Roche Molecular (Indianapolis, IN). Antibodies used for the immunohistochemical detection of BIGH3 in sectioned MTS were a gift from K. Bennett (Bristol Myers Squibb; Seattle, WA) or were polyclonal antibodies generated in New Zealand White rabbits against a BIGH3 bacterial fusion protein corresponding to amino acids 70 - 683 of the reported protein sequence [8] [9] [31] [32] [33] [34].

\subsection{Purification of BIGH3}

The serum-free conditioned medium taken from $\mathrm{CHO}$ cells expressing human $\mathrm{BIGH} 3$ was applied over heparin, hydroxyapatite and anion exchange resin bed volumes of 10 $\mathrm{ml}, 2 \mathrm{ml}$, and $2 \mathrm{ml}$, respectively. Chromatography buffers were Buffer A; $50 \mathrm{mM}$ Tris, $50 \mathrm{mM} \mathrm{NaCl}$, pH 5.5. Buffer B; Buffer A containing $1 \mathrm{M} \mathrm{NaCl}$. Buffer C; $10 \mathrm{mM} \mathrm{NaPO}_{4}$ buffer, $\mathrm{pH}$ 6.8. Buffer D; 0.4 $\mathrm{M} \mathrm{NaPO}_{4}$ buffer, $\mathrm{pH}$ 6.8. Buffer E; $10 \mathrm{mM}$ Tris, $10 \mathrm{mM}$ $\mathrm{NaCl}, \mathrm{pH}$ 5.5. Buffer $\mathrm{F}$ was comprised of Buffer E containing $1 \mathrm{M} \mathrm{NaCl}$. Purity and concentration of BIGH3 was assessed using SDS PAGE and bicinchoninic acid protein quantification (Pierce) respectively. Further details are described in the results section.

\subsection{Cell Culture}

Growth media contained $50 \mu \mathrm{g} / \mathrm{ml}$ each of penicillin and streptomycin sulfate. Cells 
were maintained in a $37^{\circ} \mathrm{C}$ incubator saturated with humidified $5 \% \mathrm{CO}_{2}$ and $95 \%$ ambient air. $\mathrm{CHO}$ cells expressing human BIGH3 were propagated in GMEM containing $10 \%$ heat-treated, dialyzed FBS and $25 \mu \mathrm{M}$ of the glutamine synthetase inhibitor methionine sulfoximine (MSX). For purification purposes, the growth medium was removed, the monolayer was rinsed three times with Hank's Balanced Salt Solution (in $\mathrm{mM} ; 1 \mathrm{CaCl}_{2}, 5.4 \mathrm{KCl}, 0.4 \mathrm{KH}_{2} \mathrm{PO}_{4}, 0.5 \mathrm{MgCl}_{2} \cdot 6 \mathrm{H}_{2} \mathrm{O}, 0.4 \mathrm{MgSO}_{4} \cdot 7 \cdot \mathrm{H}_{2} \mathrm{O}, 137 \mathrm{NaCl}, 4.2$ $\mathrm{NaHCO}_{3}, 0.4 \mathrm{Na}_{2} \mathrm{HPO}_{4}$ ) and then the cells were maintained in serum-free GMEM for 25 - 48 hours. Osteosarcoma cells and MTS were propagated in DMEM containing 0.1 $\mathrm{mM}$ non-essential amino acids, $2 \mathrm{mM}$ L-glutamine and 10\% FBS $\left(\mathrm{DMEM}^{+}\right)$. Cells were tested for mycoplasma by immunofluorescence and found negative.

\subsection{MTS Culture}

As a convenient means to study the effects of BIGH3 on MTS, we utilized an in vitro model that fosters formation of avascular MTS [35] [36] [37]. Microtiter wells coated with a solution of $0.75 \%$ agarose in DMEM were seeded with $10^{5}$ osteosarcoma cells in $\mathrm{DMEM}^{+}$. Unless otherwise noted in the text, purified recombinant BIGH3 was added to the medium to yield a final concentration of $10 \mu \mathrm{g} / \mathrm{ml}$ at the time of seeding.

\subsection{MTS Cross-Sectional Area Measurements}

Digital images of MTS were recorded utilizing a $4 \mathrm{x}$ objective on a Nikon Diaphot 200 inverted microscope interfaced with a Dage DC330 CCD camera (MCI, Inc., Michigan City, IN). The surface area is defined as the area in $\mu \mathrm{m}^{2}$ of contiguous cell contact of MTS in the culture well. Recorded images were analyzed and surface areas quantified offline using Image-Pro Plus software from Media Cybernetics (Silver Spring, MD).

\subsection{MTS Fixation, Embedding and Immunohistochemical Staining}

Day 3 osteosarcoma MTS were fixed in 4\% paraformaldehyde and embedded in paraffin. A Microm HM325 microtome (Walldorf, Germany) cut $10-\mu \mathrm{m}$ thick sections, which were then mounted onto charged microscope slides. Following deparaffinization and rehydration, sections were incubated in a solution of $0.005 \%$ trypsin-EDTA as described [38] and blocked with $10 \%$ normal goat serum. BIGH3 was detected by incubating sections at $4^{\circ} \mathrm{C}$ overnight with anti-BIGH3 antibody followed by a second antibody conjugated to horseradish peroxidase. DAB served as the chromogen substrate to localize antibodies.

\subsection{Flow Cytometry}

Osteosarcoma cells were incubated for three hours with $10 \mu \mathrm{g} / \mathrm{ml}$ BIGH3 and then washed and mixed with anti-BIGH3 antibody, $1 \mathrm{mg} / \mathrm{ml}$ anti-integrin $\beta 1$ antibody, or negative control antibody. Cells were then washed and incubated for 30 minutes with 1 $\mathrm{mg} / \mathrm{ml}$ fluorescein-conjugated goat anti-rabbit or goat anti-mouse antibody. Nonspecific fluorescence was determined by a 30-minute incubation of osteosarcoma cells with $1 \mathrm{mg} / \mathrm{ml}$ fluorescein-conjugated second antibody only. Following washes, the cells were 
fixed with 4\% paraformaldehyde in PBS (PBS in $\mathrm{mM} ; 0.7 \mathrm{CaCl}_{2}, 1.5 \mathrm{KH}_{2} \mathrm{PO}_{4}, 0.5$ $\left.\mathrm{MgCl}_{2} \cdot 6 \mathrm{H}_{2} \mathrm{O}, 137 \mathrm{NaCl}, 8.1 \mathrm{Na}_{2} \mathrm{HPO}_{4} \cdot 7 \mathrm{H}_{2} \mathrm{O}\right)$ and kept at $4^{\circ} \mathrm{C}$ until analysis. In three separate experiments flow cytometry data were collected using a Becton-Dickinson FACScan 200 fluorescent cell sorter.

\subsection{Cell Adhesion}

Substratum for osteosarcoma cells were prepared by treating microtiter wells with 10 $\mu \mathrm{g} / \mathrm{ml}$ human recombinant BIGH3. $8 \mu \mathrm{g} / \mathrm{ml}$ human fibronectin and $1 \%$ BSA in PBS. To reduce the possibility that endogenous protein synthesis may affect the outcome of adhesion experiments, DMEM containing $10 \mu \mathrm{g} / \mathrm{ml}$ cycloheximide was used to pre- incubate cells 1 hour before experiments. An identical concentration of cycloheximide was included in all subsequent adhesion assay solutions. Cells used in adhesion assays were released from monolayer culture using $1 \mathrm{mM}$ EDTA in divalent cation-free PBS, washed, and suspended at a density of $5 \times 10^{5}$ cells $/ \mathrm{ml} \mathrm{DMEM}{ }^{+}$. For integrin blocking experiments, cells were pre-incubated for one hour with function-perturbing anti-integrin antibodies (1:200 in DMEM) or control antibody. Following incubation with anti-integrin antibodies, $5 \times 10^{4}$ cells were added to each substratum and incubated for 90 minutes at $37^{\circ} \mathrm{C}$. Unattached cells were rinsed from wells and the cells remaining attached were quantified by addition of WST-1 in $\mathrm{DMEM}^{+}$followed by a two-hour incubation at $37^{\circ} \mathrm{C}$ and recording absorbance at $450 \mathrm{~nm}$.

\subsection{Statistical Analysis}

Analysis of the cell adhesion results was assessed by analysis of variance (ANOVA) and MTS formation data by the Mann-Whitney U nonparametric test. Statistical significance was accepted when $P<0.05$.

\section{Results}

Recombinant BIGH3 Purification. Serum-free medium conditioned by CHO cells expressing human BIGH3 was dialyzed against distilled water and lyophilized. The lyophilized material was rehydrated in Buffer A (Figure 1(a) and Figure 1(b), lane 1) and applied over heparin-agarose affinity column. The column was washed with three column-volumes of Buffer A, and BIGH3 was eluted between 150 - $250 \mathrm{mM} \mathrm{NaCl}$ utilizing a linear gradient of $50-500 \mathrm{mM} \mathrm{NaCl}$ (applied material, lane 1 (Figure 1(a)), heparin eluted, lane 2 Figure 1(b), lane 2 and Figure 1(c)). Protein immunoblots identified BIGH3-con- taining fractions that were pooled and applied over a hydroxyapatite column. Following washing with three column volumes of Buffer C, a 10-to-400 mM linear $\mathrm{NaPO}_{4}$ gradient eluted BIGH3 at $300 \mathrm{mM} \mathrm{NaPO}_{4}$ (Figure 1(a) and Figure 1(b), lane 3 and Figure 1(d)). Fractions that were immunoreactive for BIGH3 antiserum were pooled, applied over an anion exchange column that was then washed using three column volumes of Buffer E. A linear gradient ranging from 0.05 to $1 \mathrm{M} \mathrm{NaCl}$ was applied and BIGH3 eluted between 450 - $500 \mathrm{mM} \mathrm{NaCl}$ (Figure 1(a) and Figure 1(b), lane 4 and Figure $1(\mathrm{e})$ ). Fractions containing BIGH3 were combined and then concentrated by application 


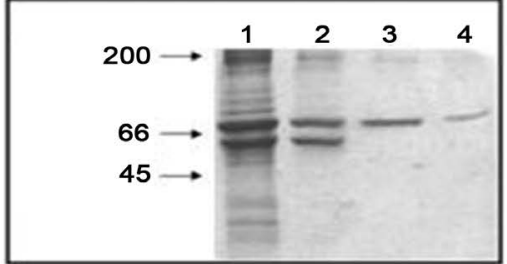

(a)

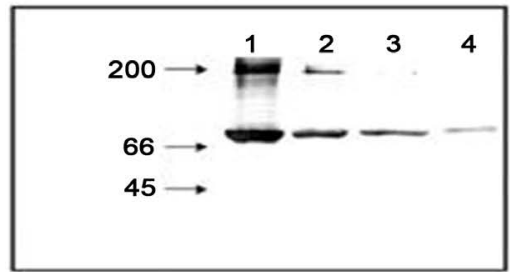

(b)



(c)

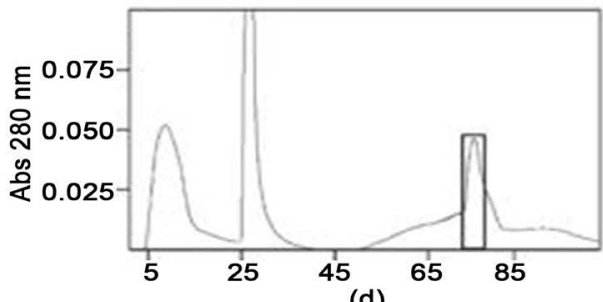

(d)

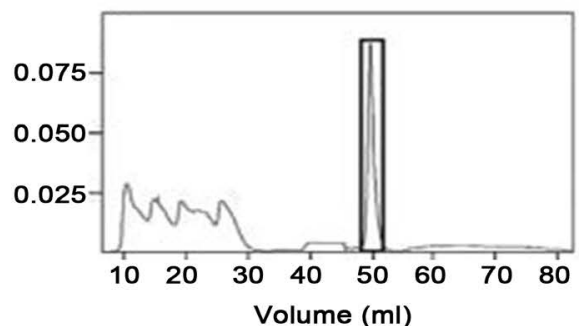

(e)

Figure 1. Recombinant BIGH3 is purified by heparin affinity, hydroxyapatite and anion exchange column chromatography. A polyacrylamide gel (a) and immunoblot (b) illustrate results of the purification paradigm for BIGH3. Starting material from growth medium conditioned by CHO cells expressing human BIGH3 (lane 1, (a) and (b)) was applied sequentially over heparin (c), hydroxyapatite (d) and anion exchange (e) resins. BIGH3 in the fractions indicated by the boxed peaks is shown ((a) and (b), lanes 2, 3 and 4, boxed peaks in (c), (d) and (e), respectively). Protein molecular mass standards are indicated as $\mathrm{kDa}$.

over a 30,000 cutoff Centricon YM membrane. The average yield from a liter of conditioned medium was $75-100 \mu \mathrm{g}$ of purified BIGH3 in PBS. The protein was stored at $-20^{\circ} \mathrm{C}$ until used for experiments.

BIGH3 Antagonizes the Formation of Osteosarcoma Spheroids. At the time of seeding recombinant BIGH3 was included in the growth medium to achieve a final concentration of $10 \mu \mathrm{g} / \mathrm{ml}$. Unless noted otherwise in the individual experiments, additional BIGH3 was not added following the initiation of the MTS cultures. During days 1 and 2, no distinct differences were detected when cells in medium containing BIGH3 were compared to osteosarcoma cells cultured under otherwise identical conditions minus exogenous BIGH3. Small MTS comprised of 3 - 30 cells were typical in the control medium, and in the medium containing BIGH3 (Figure 2(a) and Figure 2(b), respectively). Within 3 days BIGH3-treated MTS exhibited a marked impediment on the formation of MTS (Figure 2(c)) when compared to osteosarcoma MTS in control medium without BIGH3 (Figure 2(d)). Cells in the control medium began forming a large sheet-like aggregate that included the majority of cells in the well; few, if any single cells 

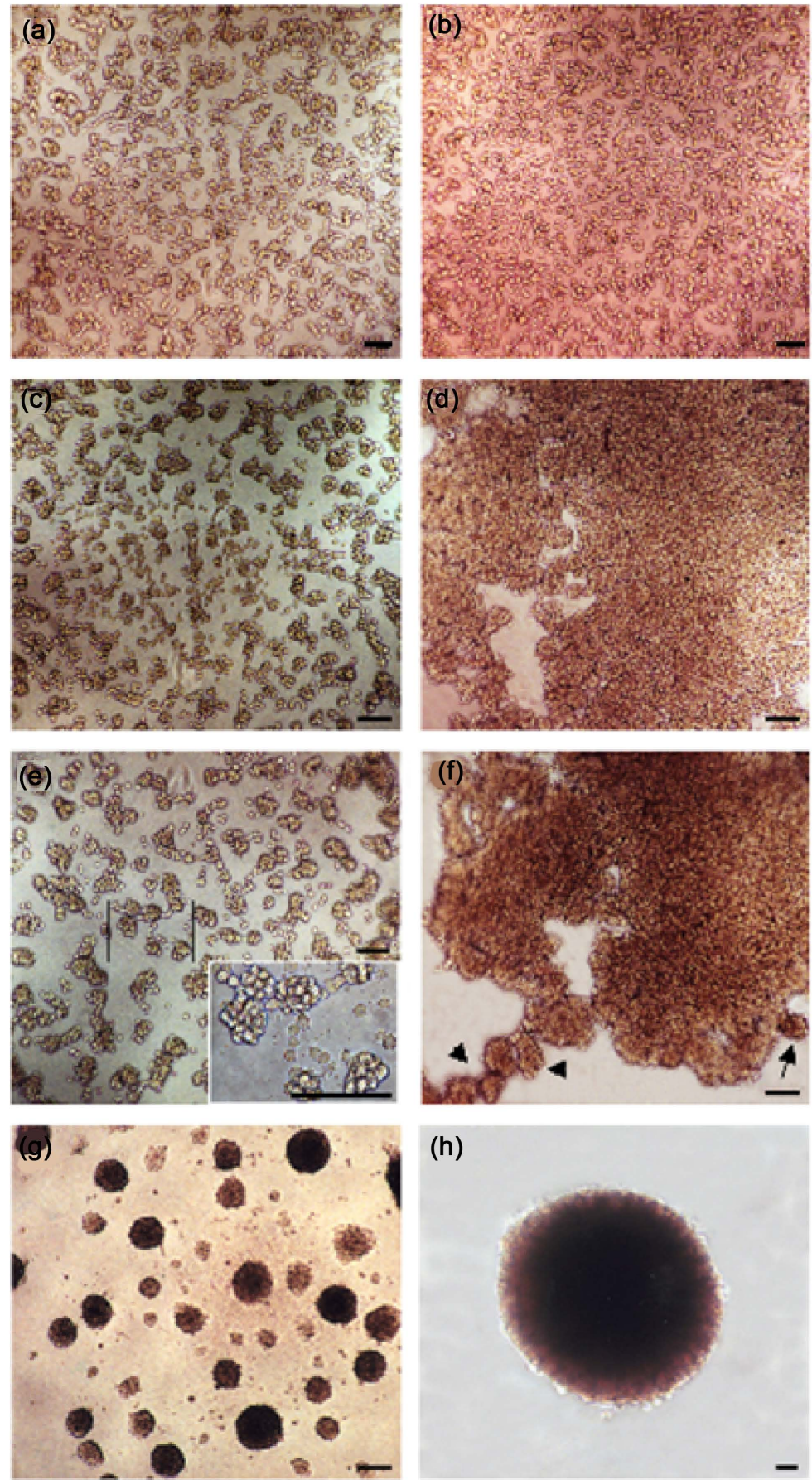

Figure 2. BIGH3 blocks progression of cells into an organized large MTS. Osteosarcoma cells were cultured in $\mathrm{DMEM}^{+}$with $10 \mu \mathrm{g} / \mathrm{ml} \mathrm{BIGH3}$ for 1, 3, 5 and 7 days ((a), (c), (e) and (g) respectively) or in identical medium without exogenous BIGH3 ((b), (d), (f) and (h), respectively). Beginning on day 3 a distinct difference is apparent when the MTS phenotype in BIGH3- treated medium (c) is compared to MTS cells in control medium (d). On day 5 small MTS only were observed in medium containing BIGH3 when compared to MTS grown in the absence of exogenous BIGH3 ((e) and (f)). The inset in (e) is an increased magnification of the small MTS formed by osteosarcoma cells in the presence of BIGH3. Differential MTS dimensions become increasingly obvious and distinct by day $7(\mathrm{~g})$ and $(\mathrm{h}))$. Scale bars represent $50 \mu \mathrm{m}$. 
and small MTS were observed in the entirety of the well (Figure 2(d)). By day 5, small MTS only were observed in medium containing BIGH3 (Figure 2(e)) when compared to non-treated cells that formed a large MTS from juxtaposed smaller aggregates of cells (Figure 2(f), arrow) and from more distant, but bound cell aggregates (Figure 2(f), arrowheads).At day 7 the MTS size in BIGH3-containing medium was markedly distinguished from controls. Small MTS had formed in medium containing exogenous BIGH3 (Figure 2(g)) whereas cells in the control medium had culminated as one, or sometimes two or three large MTS (Figure 2(h)).

Surface Tracings Show MTS Development. When the two-dimensional surface areas of BIGH3-treated and non-treated MTS were compared at 24 hours culture (Figure 2, day 1), the traced MTS surface areas were similar (Figure 3). By day 3 a marked distinction in MTS size was evident. Cells in control medium exhibited a sheet-like aggregate forming a contiguous cell mass, thus a large surface area was quantified when traced. However, there was significantly less contiguous area of cells in the BIGH3-containing medium when compared to non-treated MTS (Figure 3, day 3). By day 5 the BIGH3-treated MTS surface areas exhibited little change whereas in nontreated conditions the MTS surface area decreased as the contiguous cell sheet further compacted and organized into a MTS (Figure 3, day 5). The outcome seen at day 5 progressed further; by day 7 small MTS were combined to form a large MTS, and in the control medium the large MTS exhibited compaction. Analysis of the differences between the surface areas of BIGH3-treated and control non-treated MTS achieved statistical significance at days 3 and 5 but not at day 7, indicating that the BIGH3-mediated antagonistic effect diminished over time.

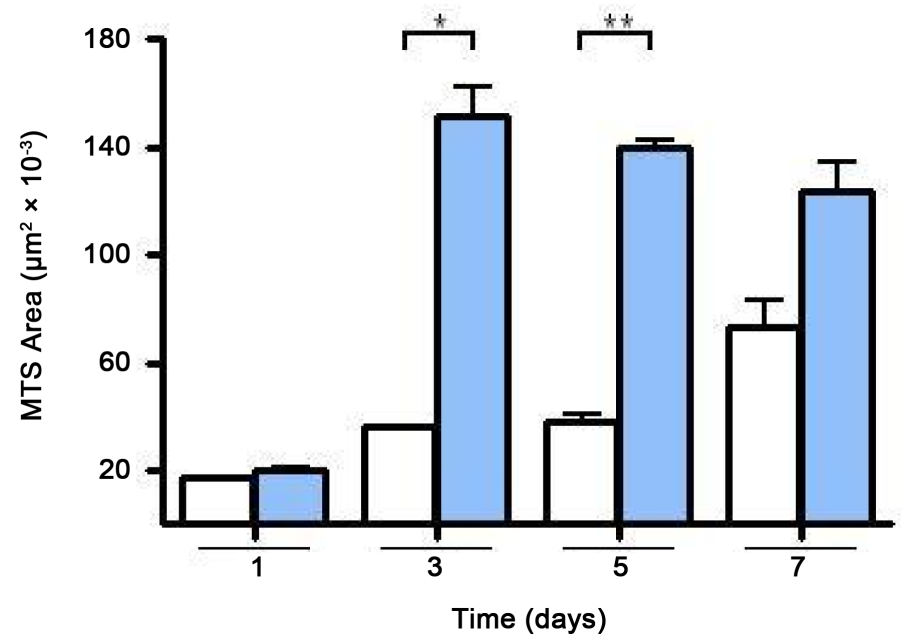

Figure 3. BIGH3 decreases the surface area of osteosarcoma cell MTS. The average two- dimensional surface area of MTS was quantified at days 1, 3, 5, and 7. At day 3 the contiguous MTS surface areas formed in the presence of exogenous BIGH3 (white columns) was significantly less than the surface area of non-treated MTS (blue columns). A statistically significant difference from the control group was achieved at days 3 and 5 ( $P \leq 0.02$ and 0.007 , respectively) as determined by the Mann-Whitney $U$ test. Differences did not achieve significance at days 1 or $7, \mathrm{n}=$ 18. 
TGF $\beta 1$ Promotes Development of Small MTS. With little, if any TGF $\beta 1$ stimulus MG-63 cells synthesize BIGH3, however, the quantity is insufficient to antagonize formation of large MTS. To determine whether the failure of non-treated cells to form large MTS was related to the quantity of BIGH3 protein in the MTS environment, we used the cytokine TGF $\beta 1$ that up regulates expression of the gene TGFBI, which encodes BIGH3 [11]. Since exogenous BIGH3 itself was sufficient to block development of large MTS phenotype, we reasoned that excluding exogenous BIGH3 from the MTS culture, and adding exogenous TGF $\beta 1$ only, would result in an increase in BIGH3 protein synthesis and block development of large MTS. Real-time PCR and Western blot analyses show that TGF $\beta 1$-treated spheroids synthesize a greater quantity of BIGH3 transcripts and protein relative to non-treated spheroids. SB-431542, a small chemical inhibitor of TGF $\beta 1$ receptor signaling blocked the increase in TGF- $\beta 1$-induced BIGH3 expression (Figure 4(a) and Figure 4(b)). The inhibitor SB-431542 lowered BIGH3 protein in the MTS itself and in the MTS medium conditioned (Figure 4(c) and Figure 4(d)). Although non-treated MTS synthesized BIGH3 large MTS formed (Figure 5(a) and Figure 5(b)). The TGF $\beta 1$-treated MTS synthesized a greater quantity of BIGH3 that was sufficient to block development of large MTS so that small MTS only developed (Figure 5(a) and Figure 5(c)). This result too implicates TGF $\beta 1$ and its activated receptor, and BIGH3 synthesis and secretion in the antagonistic pathway.

Anti-BIGH3 Antibody Blocks BIGH3's Antagonism. BIGH3 was pre-incubated with anti-BIGH3 antibody prior to adding to osteosarcoma cells in the MTS model system. Quantifying the average MTS area in treated and non-treated conditions demonstrated that anti-BIGH3 antibody significantly prevented the antagonistic effect of BIGH3 on the formation of large MTS. Osteosarcoma cells in medium containing exogenous BIGH3 (without BIGH3 antibody) formed small MTS only (Figure 6, BIGH3). A nonrelated control antibody did not block BIGH3's antagonistic effect on large MTS formation (Figure 6, BIGH3+Rabbit IgG). In contrast, an anti-BIGH3 antibody blocked BIGH3's antagonistic effect resulting in development of large MTS (Figure 6, BIGH3 + BIGH3 Ab). There was little if any difference in the large MTS areas that developed with BIGH3 antibody when compared to non-treated MTS (Figure 6, Without BIGH3). These results again indicate that BIGH3 protein itself is sufficient to suppress large MTS formation.

BIGH3 is Localized at MTS Cells and Stroma. Immunocytochemical analysis was used to investigate the spatial organization of BIGH3 in the large MTSs that formed in non-treated control conditions and in the smaller MTS that formed when the cells were treated with BIGH3. After 3 days of culture, MTS were processed for staining as described in methods section. Recombinant BIGH3 was not added to the control cultures, thus the BIGH3 protein detected represented de novo synthesized protein. BIGH3 in the large MTS was detected at cell bodies and within the interior stroma (Figure 7(a)). BIGH3 was not evident in stroma to a depth of approximately $50 \mu \mathrm{m}$ at the MTS periphery (as opposed to detection of fibronectin within this area, Figure 7(b)). In contrast, 


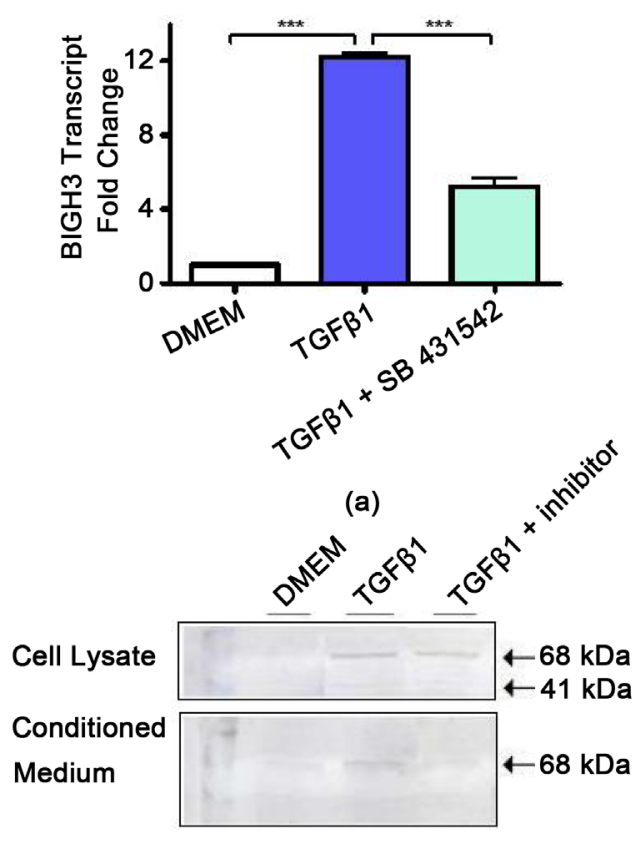

(b)

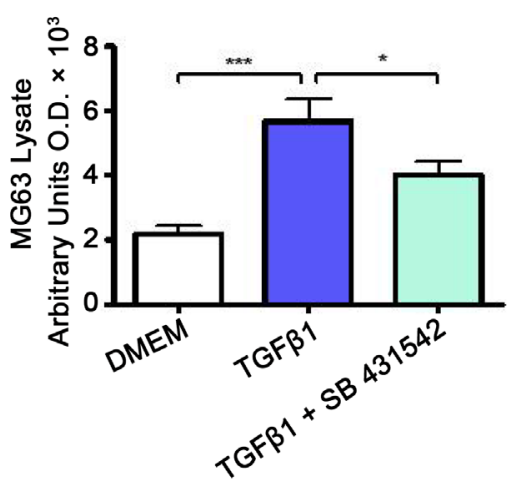

(b)

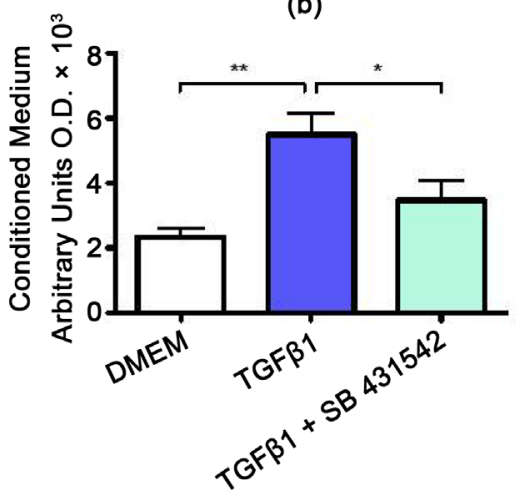

(d)

Figure 4. TGF $\beta 1$ increases the synthesis and secretion of BIGH3. (a) Shown is an increase in BIGH3 transcripts in $1.5 \times 10^{5}$ MG-63 cells cultured in DMEM with and without TGF- $\beta 1$ and SB-431542 inhibitor. BIGH3 transcript levels were significantly greater in MG-63 cells cultured in $5 \mathrm{ng} / \mathrm{mL}$ TGF- $\beta 1$ for 24 hours when compared to DMEM alone $(p<0.001)$. SB-431542 inhibitor $(13 \mu \mathrm{M})$ significantly reduced BIGH3 transcripts in TGF- $\beta 1$ stimulated cells $[\mathrm{F}(2,13)=381.4 ; \mathrm{p}<$ 0.001]. (b) Western blot of BIGH3 in the lysate and culture medium of MG-63 cells. MG-63 cells were cultured for 24 hours in DMEM alone and DMEM+ containing $5 \mathrm{ng} / \mathrm{mL}$ TGF $\beta 1$, or 5 $\mathrm{ng} / \mathrm{mL}$ TGF- $\beta 1$ plus $13 \mu \mathrm{M}$ SB-4231541 inhibitor. Loading volumes were normalized by BCA and the resolved proteins in MG-63 lysates were stained for BIGH3 (68 kDa) and actin (41 kDa). (C) Densitometry of BIGH3 bands in lysate generated from MG-63 cells cultured in $5 \mathrm{ng} / \mathrm{mL}$ TGF $\beta 1$ were significantly greater than BIGH3 in lysates of MTS cultured in DMEM alone $(p<0.001)$ and $5 \mathrm{ng} / \mathrm{mL}$ TGF- $\beta 1$ with $13 \mu \mathrm{M}$ SB-431542 inhibitor [F $(2,15)=12.92 ; p<0.05]$. (d) Densitometry of BIGH3 bands in conditioned medium from MG-63 cells cultured in 5ng/mL TGF- $\beta 1$ explains the disparity in BIGH3 transcripts (A) when compared to MG-63 cells cultured in DMEM alone $(p<0.01)$, and when cultured with $5 \mathrm{ng} / \mathrm{mL}$ TGF- $\beta 1$ plus $13 \mu \mathrm{M}$ SB-431542 inhibitor [F $(2,15)=8.214 ; p<0.05]$. One way ANOVA was performed with a post hoc Newman- Keuls Multiple Comparison test for significant differences. For each condition $n \geq 3$. Significance was set at $p<0.05$.

anti-BIGH3 antibody exhibited homogenous staining throughout MTS that formed in the presence of added recombinant BIGH3 (Figure 7(d)), similar to fibronectin staining (Figure 7(e)). MTS that formed in the presence of exogenous BIGH3 likewise exhibited homogenous staining of fibronectin (Figure $7(\mathrm{e})$ ). MTS that were in control medium and in medium containing BIGH3 did not stain with control antibody (Figure $7(c)$ and Figure 7(f), respectively). An interspersed punctum-like stain can be seen in 



Figure 5. TGF $\beta 1$ increases BIGH3 synthesis in MTS and promotes BIGH3 antagonism toward large MTS development. Cells seeded on an agarose overlay were treated with $5 \mathrm{ng} / \mathrm{ml} \mathrm{TGF} \beta 1$. After 5 days in MTS culture, cell extracts were generated from non-treated and TGF $\beta 1$-treated MTS. Western blots show an increase in BIGH3 protein in TGF $\beta 1$-treated MTS (a); In parallel experiments the growth of MTS without TGF $\beta 1$ (b) and with TGF $\beta 1$ treatment (c) were recorded, showing TGF $\beta 1$ treatment is sufficient to increase BIGH3 synthesis to a quantity that blocks large MTS formation.

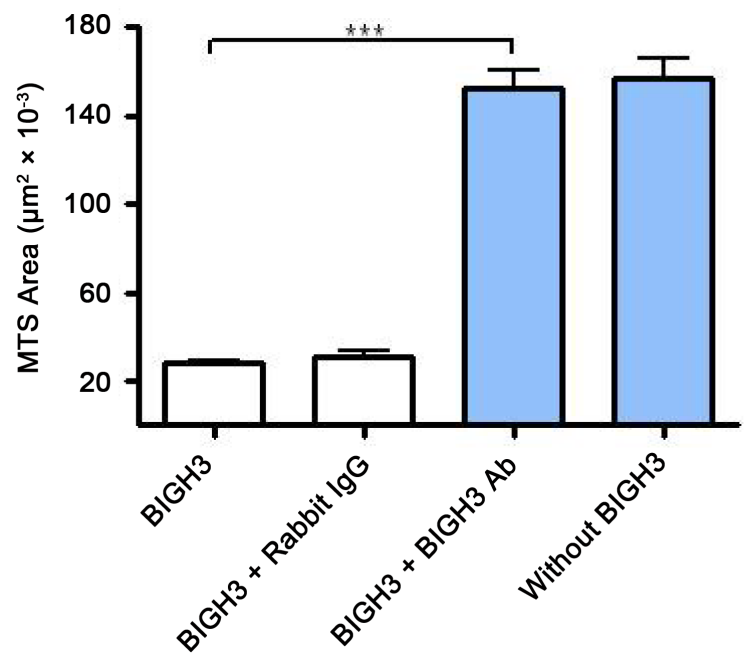

Figure 6. Anti-BIGH3 antibody blocks BIGH3 antagonism on large MTS formation. In the MTS paradigm anti-BIGH3 antibody was added at the time of cell seeding. In control conditions, exogenous BIGH3 only (BIGH3) and BIGH3 added with rabbit IgG (BIGH3 + Rabbit IgG) antagonized the formation of large MTS. In contrast, when anti-BIGH3 antibody was added with $\mathrm{BIGH} 3$, then the cells formed a contiguous large mass (BIGH3 + BIGH3 Ab) similar to the MTS that formed in control conditions (Without BIGH3). Differences in the averaged two-dimensional area of MTS formed in the presence of anti-BIGH3 antibody, when compared to the average area of control MTS, were not statistically significant ( $n=12$, Mann-Whitney $U$ test) at either day 1 (data not shown, $P \leq 0.1873$, two-tailed) or day 3 (shown here; $\mathrm{P} \leq 0.7916$, two-tailed). Error bars represent SEM. 

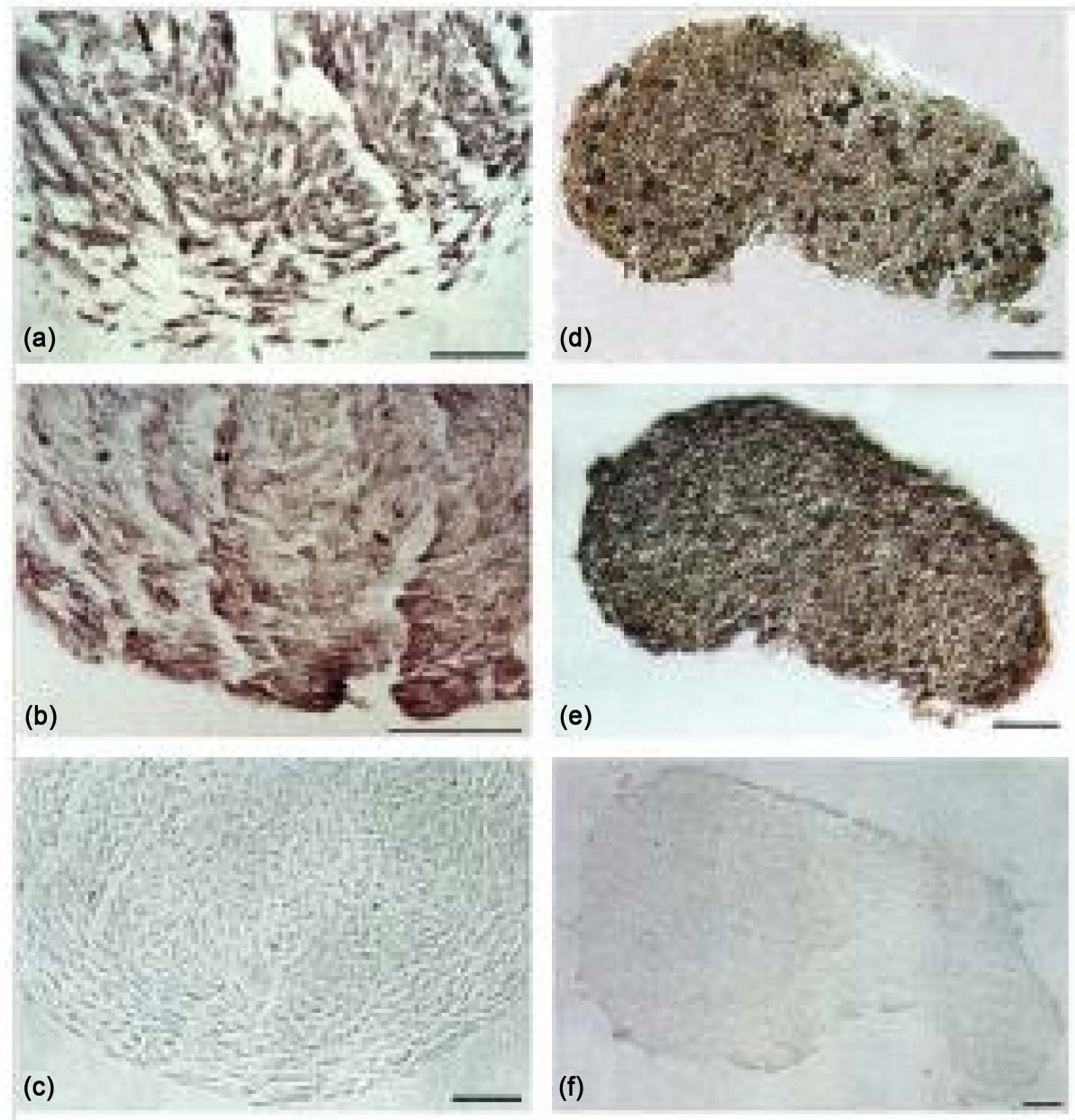

Figure 7. BIGH3 is located within MTS ECM and osteosarcoma cells. MTS formed in the MTS model in control medium ((a), (b), (c)) or medium containing $10 \mu \mathrm{g} / \mathrm{ml}$ BIGH3 protein ((d), (e), (f)) were stained with anti-BIGH3 antibody ((a) and (d)), anti-fibronectin antibody ((b) and (e)) and control antibody ((c) and (f)). BIGH3 deposition within MTS cultured in control medium was predominately at the interior stroma (a) when compared to the homogenous distribution observed in MTS cultured with exogenous BIGH3 (d). Conversely, fibronectin staining was homogenously distributed in both the presence and absence of exogenous BIGH3 protein ((b), (e)). Scale bars represent $50 \mu \mathrm{m}$.

the fibronectin stained and BIGH3 stained small spheroids. The staining was not evident in MTS prepared as frozen sections that were otherwise stained identically.

Flow Cytometry Assays Reveal Osteosarcoma Cells Bind BIGH3.The results of the immunolocalization experiments show that BIGH3 is a component of spheroid ECM, and indicates that BIGH3 associates with osteosarcoma cell-surface receptors. To investigate whether the osteosarcoma cells bind soluble BIGH3, we utilized flow cytometry. The results show that BIGH3 binds to cell surface (Figure 8(a)). As controls that indicate fluorescence intensity of known cell-surface molecules and non-specific binding, an anti- $\beta 1$ integrin antibody and control antibody were utilized (Figure 8(b) and Figure 8 (c), respectively), showing that osteosarcoma cells bind fluid-phase BIGH3. 


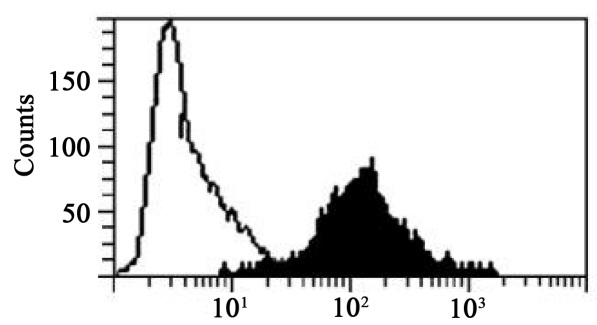

(a)



(b)



(FL1-H)

(c)

Figure 8. BIGH3 in solution binds to osteosarcoma cells. Flow cytometry shows binding of anti-BIGH3 antibody, anti- $\beta 1$ integrin antibody and control antibody ((a), (b) and (c), respectively). All panels compare the chosen antiserum to a fluorescein-conjugated antibody. Counts indicate cell number. Data shown is representative of 3 experiments for each antibody.

Integrin $\alpha 4 \beta 1$ Mediates Osteosarcoma Cell Adhesion onto a BIGH3 Substratum. Solid-phase cell adhesion assays were used to test directly and immunologically for integrins involved in osteosarcoma cell interaction with BIGH3. When seeded onto a BIGH3 substratum approximately $75 \%$ of the added osteosarcoma cells attached and spread within 90 minutes at $37^{\circ} \mathrm{C}$ (Figure 9 Untreated). MG-63 cells express the integrin subunits $\alpha 2, \alpha 3, \alpha 4, \alpha 5, \alpha 6$ and $\beta 1$ [39]. To determine whether these integrin types mediate adhesion of osteosarcoma cells to BIGH3, a set of corresponding function-perturbing anti-integrin antibodies were tested. Preincubation of cells with anti- $\alpha 4$ antibody, and anti- $\beta 1$ antibody, significantly reduced attachment of osteosarcoma cells by $92 \%$ and $93 \%$ respectively (Figure 9 Anti- $\alpha 4$ and Anti- $\beta 1, P<0.01$ ). Other anti-integrin antibodies did not achieve statistical significance. These data indicate that $\alpha 4 \beta 1$ integrin mediates MG-63 cell adhesion onto a BIGH3 substratum. Extending this observation, we hypothesized that $\alpha 4 \beta 1$ integrin promotes osteosarcoma cell MTS formation. This hypothesis was tested using the exact paradigm to generate MTS in the presence of $\alpha 4$ and $\beta 1$ antibodies. Unexpectedly, anti- $\alpha 4$ and anti- $\beta 1$ antibodies did not block the antagonistic effect of BIGH3 on MTS formation, indicating the BIGH3-me- 


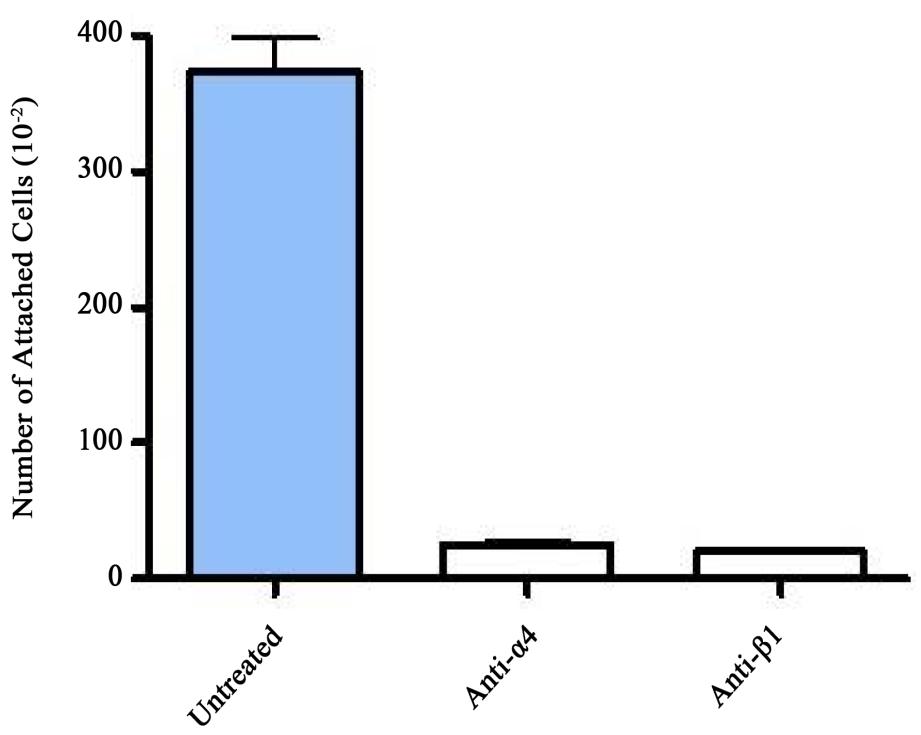

Figure 9. Anti-integrin $\alpha 4$ and $\beta 1$ antibodies reduce cell adhesion onto a BIGH3 substratum. Osteosarcoma cell attachment to a substratum comprised of $10 \mu \mathrm{g} / \mathrm{ml}$ BIGH3 (Untreated). Anti- $\alpha 4$ and Anti- $\beta 1$ integrin subunit antibodies blocked cell attachment. The reduction in cell attachment is significant $(P<0.01, \mathrm{n}=5)$ when compared to untreated conditions.

diated inhibition of large MTS formation is independent of $\alpha 4 \beta 1$, while revealing that $\alpha 4 \beta 1$ mediates osteosarcoma cell attachment to a BIGH3 substratum.

\section{Discussion}

The primary objective of this study was to document the influence of BIGH3 on osteosarcoma cell MTS development. MTS cell culture models are popular systems that support a vascular tumor growth [1] [2] [3] [4] [35] [40] [41] [42] [43]. We employed a liquid-aga- rose overlay paradigm that promoted the formation of MTS. Using TUNEL assays, we previously published findings that TGF $\beta 1$ significantly increased BIGH3 expression and apoptosis in monolayers of osteosarcoma MG-63 and Saos-2 cells [11], retinal endothelial cells [44], retinal pericytes [45], and renal tubule epithelial cells [46]. Others have shown BIGH3-mediated apoptosis in $\mathrm{CHO}$ and lung adenocarcinoma cells [47], HeLa and transformed corneal epithelial cells [48]. TGF- $\beta 1$ strongly upregulates expression of BIGH3 protein, which binds different integrins including $\alpha 1 \beta 1$ [49], $\alpha 3 \beta 1$ [50] [51], $\alpha v \beta 5$ [52], $\alpha 6 \beta 4$ [53] and $\alpha 7 \beta 1$ [54], implicating integrins in BIGH3 biology in disease. Thus, TGF $\beta 1, \mathrm{BIGH} 3$, integrins and apoptosis were highlighted as playing potential roles in osteosarcoma tumor biology. The results of this study demonstrate BIGH3 markedly blocked the progression of osteosarcoma cells to large MTS. When BIGH3 was added to MG-63 cells in our tumor model, small MTS formed only, when compared to the large MTS that formed without BIGH3, but otherwise cultured under identical conditions. This outcome formed the basis for three hypotheses that were tested in subsequent experiments in this study. First, a natural expectation was that BIGH3-mediated apoptosis was involved in the failure of osteosarcoma cells to form large MTS. Second, TGF $\beta 1$ was expected to increase BIGH3 synthesis and apop- 
tosis. A third proposition was that integrins were involved in the mechanism underlying BIGH3's inhibition of tumor growth.

TUNEL assays were used to quantify apoptosis in BIGH3-treated small MTS. The results did not conclusively demonstrate whether the impediment of large MTS formation was related to cell apoptosis. This MTS study strongly implicates BIGH3 protein as playing a causative role in the failure of osteosarcoma cells to form large MTS. Although TUNEL-positive cells were detected, the results did not achieve significance. MTS assays were typically carried out for seven days. Little, if any MTS phenotypic differences were evident for up to 2 days following initiation of the MTS cultures. By 3 days BIGH3-treated osteosarcoma cells formed small MTS comprised of a few to approximately 30 cells. Even at day 7 the small MTS phenotype consisted of approximately $1.0-1.5 \times 10^{3}$ cells, which was comparatively small relative to non-treated cells that progressed to form a sheet-like mass culminating in large MTS. IHC comparisons of BIGH3 in treated and non-treated MTS indicate a homogenous distribution of BIGH3. Intense BIGH3 staining was evident in the internal stroma of non-treated MTS, and even greater intensity throughout the treated small MTS. The latter is likely explained by the BIGH3 that was added-back to the medium in order to treat the cells. The dense punctum staining observed in treated MTS that were stained with anti-fibronectin or anti-BIGH3 antibodies will require additional experiments to determine their relevance, if any. Osteosarcoma cell de novo synthesis of BIGH3 was not sufficient to antagonize the formation of large MTS. However, adding exogenous TGF $\beta 1$ increased BIGH3 expression in the MTS and resulted in the antagonistic effect on development of large MTS. Indeed, TGF $\beta 1$-treated MTS were indistinguishable from the MTS formed when BIGH3 protein was added to the culture medium. TGF $\beta 1$ stimulates various genes encoding for molecules of the ECM. BIGH3 binds ECM molecules including proteoglycans [55], heparin (this study and [54] [56]), collagens [57], and fibronectin [56]. Thus we cannot rule out the possibility that BIGH3 interacts with different ECM molecules to bring about antagonism of large MTS. Importantly, however, whether from osteosarcoma cell synthesis or from other cellular sources in the tumor environment, anti-BIGH3 antibody blocked the BIGH3-mediated antagonism, indicating that BIGH3 protein itself, was involved in the regulation of MTS size.

Flow cytometry confirmed that osteosarcoma cells bind to soluble BIGH3 suggesting a high-affinity interaction. Osteosarcoma cell adhesion onto a 2-dimensional planar BIGH3 substratum was dependent on the concentration of BIGH3 in the substratum, and on the time of incubation, suggesting that cell interaction with BIGH3 is receptor mediated. A set of function-inhibiting anti-integrin antibodies was used to test whether integrins mediate osteosarcoma cell adhesion on BIGH3. Function-blocking anti- $\alpha 4$ and anti- $\beta 1$ antibodies inhibited more than $90 \%$ of the number of osteosarcoma cells binding to a BIGH3 substratum, implicating integrin $\alpha 4 \beta 1$ inosteosarcoma cell attachment onto a BIGH3 substratum. Integrin antibodies, including anti- $\alpha 4$ and $-\beta 1$ did not affectBIGH3's antagonism toward large MTS development when added at culture initiation, or when a 30-minute pre-incubation of osteosarcoma cells with integrin antibodies was implemented in the assay paradigm. 
Although the BIGH3 effect on MTS size is distinct, its physiological meaning is not yet apparent. One possibility that we examined is that BIGH3 functions as a tumor suppressor that diminishes tumor viability by induction of apoptosis. In support of this possibility $\mathrm{TGFBI}^{--}$mice are predisposed to form tumors when compared to wild type mice [10]. Other investigators have shown that BIGH3 is downregulated in tumors and tumor cells of mesenchyme origin, indicating a tumor suppressor role [9] [58] [59] [60] [61] [62]. We have shown that BIGH3 induces a significant increase in apoptosis in monolayers of osteosarcoma cells [11], and other different cell types [11] [44] [45] [46]. Though BIGH3-mediated apoptosis would be an attractive explanation for the antagonistic effect of BIGH3 on development of large MTS, we did not obtain convincing evidence that apoptosis was a significant influence. Additional analysis of a larger number of small spheroids and different osteosarcoma cell lines will help access the extent, if any, that BIGH3-mediated apoptosis explains, at least in part, the mechanism underlying BIGH3's antagonism on tumor growth.

An interesting alternative possibility is that BIGH3 augments tumor cell aggressiveness. The small MTS size brought about by TGF $\beta 1$ signaling and BIGH3 could provide a greater number of cells at the spheroid surfaces, and possibly increase the metastases potential. The combined surface area of small MTS would greatly exceed that of the surface area of a single large MTS of equivalent volume, where surface area $A=4 \pi r^{2}$. Assuming a mostly spheroid shape for tumors, a hypothetical "large" tumor with radius ( $r$ ) of $2.5 \mathrm{~mm}$ has an $A \approx 78.5 \mathrm{~mm}^{2}$. If hypothetical small tumor $r$ were limited to 0.5 $\mathrm{mm}$, the volume of $\approx 392$ small tumors would equate to the volume of the single large tumor. In this instance the small tumor combined surface area $A \approx 1227.8 \mathrm{~mm}^{2}$, a 15 -fold increase relative to the area of the large tumor. Small tumors could offer advantageous characteristics toward tumor survival, including increased chances of avoiding detection, greater avascular diffusion of oxygen and nutrients, and a decreased chance of necrotic tumor cell death. Previous studies report hypoxic cores develop only when MTS were $\geq 400 \mu \mathrm{m}$ diameter [63] [64] [65], however this has recently been questioned: In MG-63 osteosarcoma MTS that were $\leq 100 \mu \mathrm{m}$ diameter, hypoxia-responsive element (HRE) activity was evident, while, interestingly, HRE activity was almost undetectable in MG-63 monolayers, indicating there is different transcriptional and translational activity in 3-dimensional MTS as opposed to cell monolayers [66]. Thus small MTS of osteosarcoma cells showing high HRE activity, as with hypoxia-inducible factor 1, would potentially give rise to exceedingly aggressive cancer cells.

In summary, BIGH3 protein has a marked influence on tumorigenesis in vitro. Mechanistically, at least part of the activity includes TGFB1, TGFB1 signaling, and BIGH3 protein. Potential therapeutic targets identified in this study include TGF $\beta 1$, molecules in the TGF $\beta 1$-receptor signaling pathway, and BIGH3 itself.

\section{Acknowledgements}

The paper is supported by MBRS/SCORE grant (GM-08194, RGL) and a Faculty Research Award from the University of Texas at San Antonio (RGL). 


\section{References}

[1] Sutherland, R.M. (1988) Cell and Environment Interactions in Tumor Microregions: The Multicell Spheroid Model. Science, 240, 177-184. http://dx.doi.org/10.1126/science.2451290

[2] Haycock, J.W. (2011) 3d Cell Culture: A Review of Current Approaches and Techniques. Methods in Molecular Biology, 695, 1-15. http://dx.doi.org/10.1007/978-1-60761-984-0_1

[3] Lee, J., Cuddihy, M.J. and Kotov, N.A. (2008) Three-Dimensional Cell Culture Matrices: State of the Art. Tissue Engineering Part B: Reviews, 14, 61-86. http://dx.doi.org/10.1089/teb.2007.0150

[4] Pampaloni, F., Reynaud, E.G. and Stelzer, E.H. (2007) The Third Dimension Bridges the Gap between Cell Culture and Live Tissue. Nature Reviews Molecular Cell Biology, 8, 839845. http://dx.doi.org/10.1038/nrm2236

[5] Mueller-Klieser, W., Freyer, J.P. and Sutherland, R.M. (1986) Influence of Glucose and Oxygen Supply Conditions on the Oxygenation of Multicellular Spheroids. British Journal of Cancer, 53, 345-353. http://dx.doi.org/10.1038/bjc.1986.58

[6] Desoize, B., Gimonet, D. and Jardiller, J.C. (1998) Cell Culture as Spheroids: An Approach to Multicellular Resistance. Anticancer Research, 18, 4147-4158.

[7] Nederman, T., Norling, B., Glimelius, B., Carlsson, J. and Brunk, U. (1984) Demonstration of an Extracellular Matrix in Multicellular Tumor Spheroids. Cancer Research, 44, 30903097.

[8] Skonier, J., Neubauer, M., Madisen, L., Bennett, K., Plowman, G.D. and Purchio, A.F. (1992) cDNA Cloning and Sequence Analysis of Beta Ig-H3, a Novel Gene Induced in a Human Adenocarcinoma Cell Line after Treatment with Transforming Growth Factor- $\beta$. DNA and Cell Biology, 11, 511-522. http://dx.doi.org/10.1089/dna.1992.11.511

[9] Skonier, J., Bennett, K., Rothwell, V., Kosowski, S., Plowman, G., Wallace, P., Edelhoff, S., Disteche, C., Neubauer, M., Marquardt, H., et al. (1994) Beta Ig-H3: A Transforming Growth Factor- $\beta$-Responsive Gene Encoding a Secreted Protein That Inhibits Cell Attachment in Vitro and Suppresses the Growth of CHO Cells in Nude Mice. DNA and Cell Biology, 13, 571-584. http://dx.doi.org/10.1089/dna.1994.13.571

[10] Zhang, Y., Wen, G., Shao, G., Wang, C., Lin, C., Fang, H., Balajee, A. S., Bhagat, G., Hei, T. K. and Zhao, Y. (2009) TGFBI Deficiency Predisposes Mice to Spontaneous Tumor Development. Cancer Research, 69, 37-44. http://dx.doi.org/10.1158/0008-5472.CAN-08-1648

[11] Zamilpa, R., Rupaimoole, R., Phelix, C.F., Somaraki-Cormier, M., Haskins, W., Asmis, R. and LeBaron, R.G. (2009) C-Terminal Fragment of Transforming Growth Factor- $\beta$-Induced Protein (TGFBIp) Is Required for Apoptosis in Human Osteosarcoma Cells. Matrix Biology, 28, 347-353. http://dx.doi.org/10.1016/j.matbio.2009.05.004

[12] Shah, J.N., Shao, G., Hei, T.K. and Zhao, Y. (2008) Methylation Screening of the TGFBI Promoter in Human Lung and Prostate Cancer by Methylation-Specific PCR. BMC Cancer, 8, 284. http://dx.doi.org/10.1186/1471-2407-8-284

[13] Wen, G., Hong, M., Li, B., Liao, W., Cheng, S.K., Hu, B., Calaf, G.M., Lu, P., Partridge, M. A., Tong, J. and Hei, T.K. (2011) Transforming Growth Factor- $\beta$-Induced Protein (TGFBI) Suppresses Mesothelioma Progression through the Akt/mTOR Pathway. International Journal of Oncology, 39, 1001-1009.

[14] Zhao, Y., El-Gabry, M. and Hei, T.K. (2006) Loss of Betaig-H3 Protein Is Frequent in Primary Lung Carcinoma and Related to Tumorigenic Phenotype in Lung Cancer Cells. Molecular Carcinogenesis, 45, 84-92. http://dx.doi.org/10.1002/mc.20167

[15] Zhao, Y.L., Piao, C.Q. and Hei, T.K. (2002) Downregulation of Betaig-H3 Gene Is Causally 
Linked to Tumorigenic Phenotype in Asbestos Treated Immortalized Human Bronchial Epithelial Cells. Oncogene, 21, 7471-7477. http://dx.doi.org/10.1038/sj.onc.1205891

[16] Kang, S., Dong, S.M. and Park, N.H. (2010) Frequent Promoter Hypermethylation of TGFBI in Epithelial Ovarian Cancer. Gynecologic Oncology, 118, 58-63.

http://dx.doi.org/10.1016/j.ygyno.2010.03.025

[17] Wang, N., Zhang, H., Yao, Q., Wang, Y., Dai, S. and Yang, X. (2012) TGFBI Promoter Hypermethylation Correlating with Paclitaxel Chemoresistance in Ovarian Cancer. Journal of Experimental and Clinical Cancer Research, 31, 6. http://dx.doi.org/10.1186/1756-9966-31-6

[18] Ween, M.P., Lokman, N.A., Hoffmann, P., Rodgers, R.J., Ricciardelli, C. and Oehler, M.K. (2011) Transforming Growth Factor- $\beta$-Induced Protein Secreted by Peritoneal Cells Increases the Metastatic Potential of Ovarian Cancer Cells. International Journal of Cancer, 128, 1570-1584. http://dx.doi.org/10.1002/ijc.25494

[19] Wen, G., Partridge, M.A., Li, B., Hong, M., Liao, W., Cheng, S.K., Zhao, Y., Calaf, G.M., Liu, T., Zhou, J., Zhang, Z. and Hei, T.K. (2011) TGFBI Expression Reduces in Vitro and in Vivo Metastatic Potential of Lung and Breast Tumor Cells. Cancer Letters, 308, 23-32. http://dx.doi.org/10.1016/j.canlet.2011.04.010

[20] Son, H.N., Nam, J.O., Kim, S. and Kim, I.S. (2013) Multiple FAS1 Domains and the RGD Motif of TGFBI Act Cooperatively to Bind $\alpha v \beta 3$ Integrin, Leading to Anti-Angiogenic and Anti-Tumor Effects. Biochimica et Biophysica Acta, 1833, 2378-2388. http://dx.doi.org/10.1016/j.bbamcr.2013.06.012

[21] Guo, Y.S., Zhao, R., Ma, J., Cui, W., Sun, Z., Gao, B., He, S., Han, Y.H., Fan, J., Yang, L., Tang, J. and Luo, Z.J. (2014) Betaig-H3 Promotes Human Osteosarcoma Cells Metastasis by Interacting with Integrin $\alpha 2 \beta 1$ and Activating PI3K Signaling Pathway. PLoS ONE, 9, e90220. http://dx.doi.org/10.1371/journal.pone.0090220

[22] Ma, C., Rong, Y., Radiloff, D.R., Datto, M.B., Centeno, B., Bao, S., Cheng, A.W., Lin, F., Jiang, S., Yeatman, T.J. and Wang, X.F. (2008) Extracellular Matrix Protein Betaig-H3/ TGFBI Promotes Metastasis of Colon Cancer by Enhancing Cell Extravasation. Genes \& Development, 22, 308-321. http://dx.doi.org/10.1101/gad.1632008

[23] Tomioka, H., Morita, K., Hasegawa, S. and Omura, K. (2006) Gene Expression Analysis by cDNA Microarray in Oral Squamous Cell Carcinoma. Journal of Oral Pathology \& Medicine, 35, 206-211. http://dx.doi.org/10.1111/j.1600-0714.2006.00410.x

[24] Wong, F.H., Huang, C.Y., Su, L.J., Wu, Y.C., Lin, Y.S., Hsia, J.Y., Tsai, H.T., Lee, S.A., Lin, C.H., Tzeng, C.H., Chen, P.M., Chen, Y.J., Liang, S.C., Lai, J.M. and Yen, C.C. (2009) Combination of Microarray Profiling and Protein-Protein Interaction Databases Delineates the Minimal Discriminators as a Metastasis Network for Esophageal Squamous Cell Carcinoma. International Journal of Oncology, 34, 117-128.

[25] Ma, J., Cui, W., He, S.M., Duan, Y.H., Heng, L.J., Wang, L. and Gao, G.D. (2012) Human U87 Astrocytoma Cell Invasion Induced by Interaction of Betaig-H3 with Integrin $\alpha 5 \beta 1$ Involves Calpain-2. PLoS ONE, 7, e37297. http://dx.doi.org/10.1371/journal.pone.0037297

[26] Ahmed, A.A., Mills, A.D., Ibrahim, A.E., Temple, J., Blenkiron, C., Vias, M., Massie, C.E., Iyer, N.G., McGeoch, A., Crawford, R., Nicke, B., Downward, J., Swanton, C., Bell, S.D., Earl, H.M., Laskey, R.A., Caldas, C. and Brenton, J.D. (2007) The Extracellular Matrix Protein TGFBI Induces Microtubule Stabilization and Sensitizes Ovarian Cancers to Paclitaxel. Cancer Cell, 12, 514-527. http://dx.doi.org/10.1016/j.ccr.2007.11.014

[27] Irigoyen, M., Pajares, M.J., Agorreta, J., Ponz-Sarvise, M., Salvo, E., Lozano, M.D., Pio, R., Gil-Bazo, I. and Rouzaut, A. (2010) TGFBI Expression Is Associated with a Better Response to Chemotherapy in NSCLC. Molecular Cancer, 9, 130. 
http://dx.doi.org/10.1186/1476-4598-9-130

[28] Margadant, C. and Sonnenberg, A. (2010) Integrin-TGF- $\beta$ Crosstalk in Fibrosis, Cancer and Wound Healing. EMBO Reports, 11, 97-105. http://dx.doi.org/10.1038/embor.2009.276

[29] Wipff, P.J. and Hinz, B. (2008) Integrins and the Activation of Latent Transforming Growth Factor $\beta 1$-An Intimate Relationship. European Journal of Cell Biology, 87, 601-615. http://dx.doi.org/10.1016/j.ejcb.2008.01.012

[30] Skonier, J., Bennett, K., Rothwell, V., Kosowski, S., Plowman, G., Wallace, P., Edelhoff, S., Disteche, C., Neubauer, M., Marquardt, H., Rodgers, J. and Purchio, A.F. (1994) Beta IgH3: A Transforming Growth Factor- $\beta$-Responsive Gene Encoding a Secreted Protein That Inhibits Cell Attachment in Vitro and Suppresses the Growth of CHO Cells in Nude Mice. DNA \& Cell Biology, 13, 571-584. http://dx.doi.org/10.1089/dna.1994.13.571

[31] Ferguson, J.W., Thoma, B.S., Mikesh, M.F., Kramer, R.H., Bennett, K.L., Purchio, A., Bellard, B.J. and LeBaron, R.G. (2003) The Extracellular Matrix Protein Betaig-H3 Is Expressed at Myotendinous Junctions and Supports Muscle Cell Adhesion. Cell \& Tissue Research, 313, 93-105. http://dx.doi.org/10.1007/s00441-003-0743-Z

[32] LeBaron, R.G., Bezverkov, K.I., Zimber, M.P., Pavelec, R., Skonier, J. and Purchio, A.F. (1995) Beta Ig-H3, a Novel Secretory Protein Inducible by Transforming Growth Factor- $\beta$, Is Present in Normal Skin and Promotes the Adhesion and Spreading of Dermal Fibroblasts in Vitro. Journal of Investigative Dermatology, 104, 844-849. http://dx.doi.org/10.1111/1523-1747.ep12607024

[33] O’Brien, E.R., Bennett, K.L., Garvin, M.R., Zderic, T.W., Hinohara, T., Simpson, J.B., Kimura, T., Nobuyoshi, M., Mizgala, H., Purchio, A. and Schwartz, S.M. (1996) Beta Ig-H3, a Transforming Growth Factor- $\beta$-Inducible Gene, Is Overexpressed in Atherosclerotic and Restenotic Human Vascular Lesions. Arteriosclerosis Thrombosis and Vascular Biology, 16, 576-584. http://dx.doi.org/10.1161/01.ATV.16.4.576

[34] Rawe, I.M., Zhan, Q., Burrows, R., Bennett, K. and Cintron, C. (1997) Beta-Ig: Molecular Cloning and in Situ Hybridization in Corneal Tissues. Investigative Ophthalmology \& Visual Science, 38, 893-900.

[35] Hamilton, G. (1998) Multicellular Spheroids as an in Vitro Tumor Model. Cancer Letters, 131, 29-34. http://dx.doi.org/10.1016/S0304-3835(98)00198-0

[36] Korff, T. and Augustin, H.G. (1998) Integration of Endothelial Cells in Multicellular Spheroids Prevents Apoptosis and Induces Differentiation. Journal of Cell Biology, 143, 1341 1352. http://dx.doi.org/10.1083/jcb.143.5.1341

[37] Yuhas, J.M., Li, A.P., Martinez, A.O. and Ladman, A.J. (1977) A Simplified Method for Production and Growth of Multicellular Tumor Spheroids. Cancer Research, 37, 36393643.

[38] Perrot-Applanat, M., Groyer-Picard, M.T., Lorenzo, F., Jolivet, A., Vu Hai, M.T., Pallud, C., Spyratos, F. and Milgrom, E. (1987) Immunocytochemical Study with Monoclonal Antibodies to Progesterone Receptor in Human Breast Tumors. Cancer Research, 47, 2652-2661.

[39] Lisignoli, G., Monaco, M.G., Toneguzzi, S., Bertollini, V., Cattini, L. and Facchini, A. (1995) FACS Analysis of Osteosarcoma Cell Line (MG-63) Integrin Subfamilies. Bollettino della Società Italiana di Biologia Sperimentale, 71, 309-315.

[40] Durand, R.E. (1990) Multicell Spheroids as a Model for Cell Kinetic Studies. Cell \& Tissue Kinetics, 23, 141-159.

[41] Enmon Jr., R.M., O’Connor, K.C., Lacks, D.J., Schwartz, D.K. and Dotson, R.S. (2001) Dynamics of Spheroid Self-Assembly in Liquid-Overlay Culture of Du 145 Human Prostate Cancer Cells. Biotechnology and Bioengineering, 72, 579-591. 
http://dx.doi.org/10.1002/1097-0290(20010320)72:6<579::AID-BIT1023>3.0.CO;2-L

[42] Santini, M.T. and Rainaldi, G. (1999) Three-Dimensional Spheroid Model in Tumor Biology. Pathobiology, 67, 148-157. http://dx.doi.org/10.1159/000028065

[43] Santini, M.T., Rainaldi, G. and Indovina, P.L. (2000) Apoptosis, Cell Adhesion and the Extracellular Matrix in the Three-Dimensional Growth of Multicellular Tumor Spheroids. Critical Reviews in Oncology/ Hematology, 36, 75-87. http://dx.doi.org/10.1016/S1040-8428(00)00078-0

[44] Mondragon, A.A., Betts-Obregon, B.S., Moritz, R.J., Parvathaneni, K., Navarro, M.M., Kim, H.S., Lee, C.F., LeBaron, R.G., Asmis, R. and Tsin, A.T. (2015) BIGH3 Protein and Macrophages in Retinal Endothelial Cell Apoptosis. Apoptosis, 20, 29-37.

http://dx.doi.org/10.1007/s10495-014-1052-6

[45] Betts-Obregon, B.S., Mondragon, A.A., Mendiola, A.S., LeBaron, R.G., Asmis, R., Zou, T., Gonzalez-Fernandez, F. and Tsin, A.T. (2016) TGF- $\beta$ Induces BIGH3 Expression and Human Retinal Pericyte Apoptosis: A Novel Pathway of Diabetic Retinopathy. Eye, Epub.

[46] Moritz, R.J., LeBaron, R.G., Phelix, C.F., Rupaimoole, R., Tsin, A. and Asmis, R. (2016) Macrophage TGF- $\beta 1$ and the Proapoptotic Extracellular Matrix Protein Bigh3 Induce Renal Cell Apoptosis in Prediabetic and Diabetic Conditions. International Journal of Clinical Medicine, 7, 496-510. http://dx.doi.org/10.4236/ijcm.2016.77055

[47] Kim, J.E., Kim, S.J., Jeong, H.W., Lee, B.H., Choi, J.Y., Park, R.W., Park, J.Y. and Kim, I.S. (2003) RGD Peptides Released from Beta Ig-H3, a TGF- $\beta$-Induced Cell-Adhesive Molecule, Mediate Apoptosis. Oncogene, 22, 2045-2053. http://dx.doi.org/10.1038/sj.onc.1206269

[48] Morand, S., Buchillier, V., Maurer, F., Bonny, C., Arsenijevic, Y., Munier, F.L. and Schorderet, D.F. (2003) Induction of Apoptosis in Human Corneal and Hela Cells by Mutated BIGH3. Investigative Ophthalmology \& Visual Science, 44, 2973-2979. http://dx.doi.org/10.1167/iovs.02-0661

[49] Ohno, S., Noshiro, M., Makihira, S., Kawamoto, T., Shen, M., Yan, W., Kawashima-Ohya, Y., Fujimoto, K., Tanne, K. and Kato, Y. (1999) RGD-CAP ((Beta)Ig-H3) Enhances the Spreading of Chondrocytes and Fibroblasts Via Integrin $\alpha(1) \beta(1)$. Biochimica et Biophysica Acta, 1451, 196-205. http://dx.doi.org/10.1016/S0167-4889(99)00093-2

[50] Kim, J.E., Kim, S.J., Lee, B.H., Park, R.W., Kim, K.S. and Kim, I.S. (2000) Identification of Motifs for Cell Adhesion within the Repeated Domains of Transforming Growth Factor- $\beta$-Induced Gene, Betaig-H3. Journal of Biological Chemistry, 275, 30907-30915. http://dx.doi.org/10.1074/jbc.M002752200

[51] Oh, J.E., Kook, J.K. and Min, B.M. (2005) Beta Ig-H3 Induces Keratinocyte Differentiation Via Modulation of Involucrin and Transglutaminase Expression through the Integrin $\alpha 3 \beta 1$ and the Phosphatidylinositol 3-Kinase/Akt Signaling Pathway. Journal of Biological Chemistry, 280, 21629-21637. http://dx.doi.org/10.1074/jbc.M412293200

[52] Kim, J.E., Jeong, H.W., Nam, J.O., Lee, B.H., Choi, J.Y., Park, R.W., Park, J.Y. and Kim, I.S. (2002) Identification of Motifs in the Fasciclin Domains of the Transforming Growth Factor-Beta-Induced Matrix Protein Betaig-H3 That Interact with the $\alpha v \beta 5$ Integrin. Journal of Biological Chemistry, 277, 46159-46165. http://dx.doi.org/10.1074/jbc.M207055200

[53] Kim, M.O., Yun, S.J., Kim, I.S., Sohn, S. and Lee, E.H. (2003) Transforming Growth Factor- $\beta$-Inducible Gene-H3 (Beta(Ig)-H3) Promotes Cell Adhesion of Human Astrocytoma Cells in Vitro: Implication of $\alpha 6 \beta 4$ Integrin. Neuroscience Letters, 336, 93-96. http://dx.doi.org/10.1016/S0304-3940(02)01260-0

[54] Ferguson, J.W., Mikesh, M.F., Wheeler, E.F. and LeBaron, R.G. (2003) Developmental Expression Patterns of Beta-Ig (Betaig-H3) and Its Function as a Cell Adhesion Protein. $\mathrm{Me}$ - 
chanisms of Development, 120, 851-864. http://dx.doi.org/10.1016/S0925-4773(03)00165-5

[55] Reinboth, B., Thomas, J., Hanssen, E. and Gibson, M.A. (2006) Beta Ig-H3 Interacts Directly with Biglycan and Decorin, Promotes Collagen Vi Aggregation, and Participates in Ternary Complexing with These Macromolecules. Journal of Biological Chemistry, 281, 7816-7824. http://dx.doi.org/10.1074/jbc.M511316200

[56] Billings, P.C., Whitbeck, J.C., Adams, C.S., Abrams, W.R., Cohen, A.J., Engelsberg, B.N., Howard, P.S. and Rosenbloom, J. (2002) The Transforming Growth Factor- $\beta$-Inducible Matrix Protein (Beta)Ig-H3 Interacts with Fibronectin. Journal of Biological Chemistry, 277, 28003-28009. http://dx.doi.org/10.1074/jbc.M106837200

[57] Hashimoto, K., Noshiro, M., Ohno, S., Kawamoto, T., Satakeda, H., Akagawa, Y., Nakashima, K., Okimura, A., Ishida, H., Okamoto, T., Pan, H., Shen, M., Yan, W. and Kato, Y. (1997) Characterization of a Cartilage-Derived 66-KDa Protein (RGD-CAP/Beta Ig-H3) That Binds to Collagen. Biochimica et Biophysica Acta, 1355, 303-314.

http://dx.doi.org/10.1016/S0167-4889(96)00147-4

[58] Dokmanovic, M., Chang, B.D., Fang, J. and Roninson, I.B. (2002) Retinoid-Induced Growth Arrest of Breast Carcinoma Cells Involves Co-Activation of Multiple Growth-Inhibitory Genes. Cancer Biology \& Therapy, 1, 24-27. http://dx.doi.org/10.4161/cbt.1.1.35

[59] Genini, M., Schwalbe, P., Scholl, F.A. and Schafer, B.W. (1996) Isolation of Genes Differentially Expressed in Human Primary Myoblasts and Embryonal Rhabdomyosarcoma. International Journal of Cancer, 66, 571-577. http://dx.doi.org/10.1002/(SICI)1097-0215(19960516)66:4<571::AID-IJC24>3.0.CO;2-9

[60] Schenker, T. and Trueb, B. (1998) Down-Regulated Proteins of Mesenchymal Tumor Cells. Exp Cell Res, 239, 161-168. http://dx.doi.org/10.1006/excr.1997.3896

[61] Zhang, L., Zhou, W., Velculescu, V.E., Kern, S.E., Hruban, R.H., Hamilton, S.R., Vogelstein, B. and Kinzler, K.W. (1997) Gene Expression Profiles in Normal and Cancer Cells. Science, 276, 1268-1272. http://dx.doi.org/10.1126/science.276.5316.1268

[62] Zhao, Y.L., Piao, C.Q. and Hei, T.K. (2002) Overexpression of Betaig-H3 Gene Downregulates Integrin $\alpha 5 \beta 1$ and Suppresses Tumorigenicity in Radiation-Induced Tumorigenic Human Bronchial Epithelial Cells. British Journal of Cancer, 86, 1923-1928. http://dx.doi.org/10.1038/sj.bjc.6600304

[63] Groebe, K. and Mueller-Klieser, W. (1996) On the Relation between Size of Necrosis and Diameter of Tumor Spheroids. International Journal of Radiation Oncology, Biology, Physics, 34, 395-401. http://dx.doi.org/10.1016/0360-3016(95)02065-9

[64] Kunz-Schughart, L.A., Doetsch, J., Mueller-Klieser, W. and Groebe, K. (2000) Proliferative Activity and Tumorigenic Conversion: Impact on Cellular Metabolism in 3-D Culture. American Journal of Physiology - Cell Physiology, 278, C765-C780.

[65] Serganova, I., Doubrovin, M., Vider, J., Ponomarev, V., Soghomonyan, S., Beresten, T., Ageyeva, L., Serganov, A., Cai, S., Balatoni, J., Blasberg, R. and Gelovani, J. (2004) Molecular Imaging of Temporal Dynamics and Spatial Heterogeneity of Hypoxia-Inducible Factor-1 Signal Transduction Activity in Tumors in Living Mice. Cancer Research, 64, 61016108. http://dx.doi.org/10.1158/0008-5472.CAN-04-0842

[66] Indovina, P., Collini, M., Chirico, G. and Santini, M.T. (2007) Three-Dimensional Cell Organization Leads to Almost Immediate HRE Activity as Demonstrated by Molecular Imaging of MG-63 Spheroids Using Two-Photon Excitation Microscopy. FEBS Letters, 581, 719726. http://dx.doi.org/10.1016/j.febslet.2007.01.040 
Submit or recommend next manuscript to SCIRP and we will provide best service for you:

Accepting pre-submission inquiries through Email, Facebook, LinkedIn, Twitter, etc. A wide selection of journals (inclusive of 9 subjects, more than 200 journals)

Providing 24-hour high-quality service

User-friendly online submission system

Fair and swift peer-review system

Efficient typesetting and proofreading procedure

Display of the result of downloads and visits, as well as the number of cited articles

Maximum dissemination of your research work

Submit your manuscript at: http://papersubmission.scirp.org/

Or contactijcm@scirp.org 